\title{
Multi-disciplinary investigation of fluid seepage on an unstable margin: The case of the Central Nile deep sea fan
}

\author{
G. Bayon ${ }^{a,{ }^{*}}$, L. Loncke ${ }^{b}$, S. Duprée ${ }^{a, c}$, J.-C. Caprais ${ }^{d}$, E. Ducassou ${ }^{e}$, S. Duperron ${ }^{f}, J$.
} Etoubleau $^{\mathrm{a}}$, J.-P. Foucher ${ }^{\mathrm{a}}$, Y. Fouquet ${ }^{\mathrm{a}}$, S. Gontharet ${ }^{\mathrm{g}}$, G.M. Henderson ${ }^{\mathrm{h}}$, C. Huguen', I.

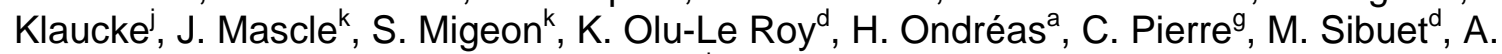
Stadnitskaial and J. Woodside ${ }^{c}$

\author{
${ }^{a}$ Département Géosciences Marines, IFREMER, Brest, France \\ ${ }^{\mathrm{b}}$ UMR 8110, Université de Picardie Jules Verne, Amiens, France \\ ${ }^{c}$ Sedimentology and Marine Geology Department, Vrije Universiteit, Amsterdam, The Netherlands \\ ${ }^{\mathrm{d}}$ Département Etude des Ecosystèmes Profonds, IFREMER, Brest, France \\ e UMR 5805 EPOC, Université de Bordeaux 1, France \\ ${ }^{f}$ UMR 7138, Université Pierre et Marie Curie, Paris, France \\ ${ }^{\mathrm{g}}$ LOCEAN, Université Pierre et Marie Curie, Paris, France \\ ${ }^{\mathrm{h}}$ Department of Earth Sciences, University of Oxford, UK \\ ' LEGEM, Université de Perpignan, Perpignan, France \\ 'IFM-GEOMAR, Kiel, Germany \\ k Géosciences Azur UMR 6526, Villefranche-sur-mer, France \\ 'Royal Netherlands Institute for Sea Research, Texel, The Netherlands
}

*: Corresponding author: G. Bayon, Tel.: +33 2982246 30; fax: +33 29822 45 70, email address : Germain.Bayon@ifremer.fr

\begin{abstract}
:
We report on a multidisciplinary study of cold seeps explored in the Central Nile deep-sea fan of the Egyptian margin. Our approach combines in situ seafloor observation, geophysics, sedimentological data, measurement of bottom-water methane anomalies, pore-water and sediment geochemistry, and ${ }^{230} \mathrm{Th} / \mathrm{U}$ dating of authigenic carbonates. Two areas were investigated, which correspond to different sedimentary provinces. The lower slope, at $\sim 2100 \mathrm{~m}$ water depth, indicates deformation of sediments by gravitational processes, exhibiting slope-parallel elongated ridges and seafloor depressions. In contrast, the middle slope, at not, vert, $\sim 1650 \mathrm{~m}$ water depth, exhibits a series of debris-flow deposits not remobilized by post-depositional gravity processes.
\end{abstract}

Significant differences exist between fluid-escape structures from the two studied areas. At the lower slope, methane anomalies were detected in bottom-waters above the depressions, whereas the adjacent ridges show a frequent coverage of fractured carbonate pavements associated with chemosynthetic vent communities. Carbonate U/Th age dates ( $~ 8 \mathrm{kyr}$ BP), pore-water sulphate and solid phase sediment data suggest that seepage activity at those carbonate ridges has decreased over the recent past. In contrast, large $(\sim 1 \mathrm{~km} 2)$ carbonate-paved areas were discovered in the middle slope, with $\mathrm{U} / \mathrm{Th}$ isotope evidence for ongoing carbonate precipitation during the Late Holocene (since $\sim 5 \mathrm{kyr}$ BP at least).

Our results suggest that fluid venting is closely related to sediment deformation in the Central Nile margin. It is proposed that slope instability leads to focused fluid flow in the lower slope and exposure of 'fossil' carbonate ridges, whereas pervasive diffuse flow prevails at the unfailed middle slope.

Keywords: Nile; continental margin; cold seep; U-Th; authigenic carbonate 


\section{1 - Introduction}

60 Submarine pockmarks are widespread features on continental margins, which are

61 often related to seepage of gas-rich fluids at the seafloor and/or to the presence of gas

62 hydrates in marine sediments (e.g. Hovland and Judd, 1988; Judd and Hovland, 2007).

63 Over recent years, there has been much interest in the study of seafloor pockmarks

64 because they represent potential pathways for important quantities of gas from sediments

65 to the ocean and, perhaps, to the atmosphere (e.g. Vogt et al., 1999; Paull et al., 2002;

66 Ussler et al., 2003; Dimitrov and Woodside, 2003; Hovland et al., 2002, 2005; Gay et al.,

67 2006). In active seepage sites, expulsion of gas-rich fluids commonly supports the

68 development of chemosynthetic communities and the formation of authigenic carbonates,

69 both of which are of interest for the understanding of biogeochemical and

70 microbiological processes related to fluid seeping.

71 Increasing evidence of vast submarine pockmark fields in areas of destabilised

72 seafloor sediments has questioned the relationship between slope instability and fluid

73 circulation on continental margins (e.g. Hovland et al., 2002; Gay et al., 2004; Lastras et

74 al., 2004; Loncke et al., 2004; Trincardi et al., 2004). Are sediment slides responsible for

75 fluid release on the seafloor or, instead, does fluid circulation within margin sediments

76 favour mass movements? A recent compilation of published dates for major submarine

77 failures occurring in the North Atlantic area has shown that most sediment failures took

78 place during two distinct periods over the last 45,000 years: the Bølling-Ållerød (15 - 13

$79 \mathrm{ka})$ and the Preboreal (11 - $8 \mathrm{ka})$, which correlate with peaks of enhanced atmospheric

80 methane concentrations recorded in ice cores (Maslin et al., 2004). It has been speculated

81 that dissociation of gas hydrates in marine sediments, in response to environmental 
82 changes, has been instrumental in triggering such sediment failures, possibly releasing

83 significant quantities of methane into the atmosphere (e.g. Paull et al., 2000; Nisbet,

84 2002; Kennett et al., 2002; Mienert et al., 2005). Isotopic records of atmospheric $\mathrm{CH}_{4}$ in

85 ice cores suggest, however, that marine gas hydrate reservoirs have remained stable

86 during the Late Quaternary (Sowers, 2006). In-depth investigations of selected key

87 regions are now needed, however, to bring further insights on the mechanisms linking

88 slope instabilities, fluid circulation and methane emission on continental margins (e.g.

89 Mienert, 2004).

91 Here, we report on a multidisciplinary study of cold seeps and mass movements

92 explored off Egypt (Eastern Mediterranean basin), which brings interesting information

93 on the relationship between fluid seepage and slope instabilities on continental margins.

94 Fluid-related structures are particularly abundant in the central province of the Nile deep-

95 sea fan, between 1500 and 2500 m water depth - an area where sediments are completely

96 destabilised by gravitational processes (Loncke et al., 2002; Loncke et al., 2004).

97 Selected targets of the Nile deep-sea fan were explored during two expeditions (Nautinil

982003 - R/V Atalante; Mimes 2004 - R/V Pelagia), funded through the MEDIFLUX

99 project (ESF Euromargins Programme). This work represents a synthesis of in situ

100 seafloor observation with the Nautile submersible, geophysical (3.5 kHz profiles, deep-

101 tow sidescan sonar seafloor imagery), sedimentological and geochemical data (dissolved

102 sulphate, elemental analyses, ${ }^{230} \mathrm{Th} / \mathrm{U}$ carbonate ages), some of which include preliminary

103 results.

104 
106 The Nile deep sea fan is a large sedimentary wedge, which has developed mainly since 107 the Late Miocene in the eastern Mediterranean Sea (e.g. Salem, 1976). The morphology

108 of the Nile deep sea fan results from the complex interplay between pre-Messinian 109 inherited topography, salt-related deformation, and sediment gravity processes. Salt 110 tectonism (e.g. diapirism, gravity spreading and gliding) on the Nile margin is related to 111 the presence of a ductile Messinian salt layer within the sedimentary edifice (Mascle et 112 al., 2000; Gaullier et al., 2000; Loncke et al., 2006). Sediment mass-wasting (e.g. 113 slumping, debris flows) has occurred on the entire Nile fan, in response to various 114 processes, such as salt-tectonism, sediment overloading and fluid circulation. In 115 particular, the Central Nile Province is characterized by a highly destabilised seafloor 116 surface, which shows repeated sediment failures and debris flows (Loncke et al., 2002; 117 Loncke et al., 2004). Loncke et al. (2004) suggested that sediment instability in the 118 Central Nile Province may be related to circulation of gas-rich fluids within sub-surface 119 sediments.

121 A large number of seafloor structures related to fluid venting were recognised on the 122 Nile margin during recent geophysical surveys (Fig. 1; Bellaiche et al., 2001; Loncke et 123 al., 2002; Loncke et al., 2004). Numerous gas chimneys and associated mud volcanoes 124 and cones were identified in Eastern (e.g. Isis, Amon, Osiris; see Fig. 1) and Western 125 provinces. Many of these structures have been emplaced in areas where Messinian salt 126 layers are absent in the sedimentary cover or have thinned down significantly, thereby 127 allowing deep pre-Messinian fluids to migrate upward along major faults. Other smaller 
128 seafloor structures related to fluid venting were identified on the Nile margin from ship129 borne multibeam acoustic images. They correspond to numerous highly-reflective 130 patches, attributed to small pockmarks and/or mounds (Fig. 1; Loncke et al., 2004).

131 Those patches are clustered in two areas (Fig. 1): in the Eastern province, in close 132 proximity to gas chimneys; and in the Central Nile Province, associated with destabilized 133 sediments. In the Central Province, those highly reflective acoustic patches occur mainly 134 at water depths ranging from $\sim 500 \mathrm{~m}$ down to $2500 \mathrm{~m}$. One important objective of the 135 MEDIFLUX project was to characterise those acoustic patches identified on ship-borne 136 multibeam seafloor maps and to establish their relationship with fluid seepage and slope 137 instability.

1403 - Materials and Methods

141 3.1. Geophysics

142 An extensive set of geophysical data (3.5 kHz profiles, Simrad EM12-Dual and EM300-

143 Dual multibeam echosounder and seismic data) was acquired during the Nautinil 2003 144 expedition, as well as during previous Géosciences-Azur cruises (PrismedII 1998, Fanil 1452000 and Vanil 2004), which provided bathymetric and acoustic maps for the entire Nile 146 deep sea fan (Loncke et al., 2004). Multibeam EM12- and EM-300 data were combined 147 and processed at a grid size of 50m/pixel, using the Caraïbes software. High-resolution 148 EdgeTech DTS-1 side-scan sonar data were acquired during the Mimes 2004 expedition. 149 The deep tow side scan sonar was deployed and towed at around $100 \mathrm{~m}$ above the 150 seafloor and operated at a $75-\mathrm{kHz}$ frequency, with a $1500 \mathrm{~m}$ wide swath of the seafloor. 
153 Nautile dives took place in two different areas on the Central Nile Province: 1) the lower 154 slope, at 2100 m water depth (dives NL6 and NL14; Fig. 1), and 2) the middle slope, at 155 1650 m water depth (dive NL7; Fig. 2B,C). Microbathymetric profiles along each dive 156 transect were acquired using Nautile sensors (pressure sensor and sounder). A methane 157 sensor (Capsum METS) was installed on the Nautile frame to detect methane in bottom158 waters. Note that concentrations measured with the methane sensor are qualitative only.

$160 \quad 3.3$. Sediment cores

161 A set of push-cores and blade-cores (i.e. a submersible-mounted corer equipped with a 162 guillotine-like cutter, which allows efficient sampling of unconsolidated sediments) was 163 collected in the Central Nile province during the Nautile dives. One piston core (NLK11) 164 was also collected from the lower slope during the Nautinil cruise. The position of all 165 sediment cores used for this study is given in Table 1 and shown in Figs. 1, 3B,C and 4. 166 Push-cores NL14-PC1 and NL14-PC3 were retrieved in carbonate ridge areas (see 167 description of fluid-venting structures in section 4.2). Push-core NL6-PC1 was collected 168 from a small pockmark on the lower slope. The blade core NL7-BC1 is a reference core 169 recovered in the middle slope, away from fluid venting structures. The lithological 170 description for those cores is presented in Fig. 5. Hemipelagic sediments in the Nile deep 171 sea fan correspond typically to reddish-brown foraminiferal and pteropod oozes (core 172 NL7-BC1; uppermost part of cores NL14-PC1/3). In contrast, dark-grey sediments are 173 encountered frequently at cold seep sites (core NL6-PC1; lower part of cores NL14-PC 
174 1/3), which may contain small (mm- to $\mathrm{cm}$ - size) concretions of authigenic carbonates 175 (Fig. 5).

177 3.4. Sediment geochemistry and pore water analyses

178 The inorganic geochemical composition of authigenic carbonates and sediments was 179 determined by wavelength dispersive X-ray fluorescence (WD-XRF) analysis of fusion 180 beads or compressed powder pellets for major and trace elements, respectively. Both 181 total and oxidised $\left(\mathrm{SO}_{4}\right)$ sulphur contents of sediment samples were measured by XRF, 182 allowing the determination of reduced sulphur concentrations (e.g. pyrite) by subtraction. 183 Pore waters were extracted from core NL14-PC1 sediments by centrifuge. Dissolved 184 sulphate concentrations were measured in 1:10 diluted solutions by ion chromatography 185 with an accuracy better than $4 \%$.

187 3.5. U/Th dating of authigenic carbonates

188 Bayon et al. (2007) reported ${ }^{230} \mathrm{Th} / \mathrm{U}$ ages for a set of samples drilled across a 189 carbonate crust recovered from the middle slope (NL7-CC2 crust; see location in Fig. 4), 190 which provided evidence for continuous carbonate precipitation at that studied location 191 over the last $\sim 5000$ years at least. In this study, we performed additional U-Th isotope 192 measurements for two other carbonate crusts (NL6-CC1 and NL14-CC5; see location in 193 Figs. 3B,C), collected from carbonate ridges in the lower slope. NL6-CC1 and NL14194 CC5 crusts correspond to carbonate pavements characterized by a homogeneous matrix 195 of terrigenous sediment (silt, clay), foraminifers and nannofossils, cemented by fine196 grained aragonite (Gontharet et al., 2007). 
197 Details on chemical and analytical procedures are presented elsewhere (Bayon et al., 198 2007), and a brief description is given here. Selected areas of carbonate crusts were 199 hand-drilled carefully to obtain $100 \mathrm{mg}$ of carbonate powder. Carbonate samples were 200 spiked with a mixed ${ }^{236} \mathrm{U}^{229} \mathrm{Th}$ spike prior to sample digestion. $\mathrm{U}$ and Th were then 201 separated chemically using conventional anion exchange techniques. $U$ and Th 202 concentrations and isotope ratios were measured by multiple collector inductively 203 coupled plasma mass spectrometry (MC-ICPMS) at the University of Oxford. Detrital 204 contamination was typically too high for allowing calculation of ages using the

205 conventional ${ }^{230}$ Th age equation and required instead the use of isochron methods (e.g. 206 Bourdon et al., 2003). For this approach, a sediment end-member was defined as the 207 average of two sediments from the studied area (Bayon et al., 2007), assumed to be 208 representative of the sediment fraction incorporated within the carbonate crusts.

$210 \quad 4$ - Results

211 4.1. Morphology of the Central Nile Province

212 New geophysical data acquired during the Nautinil cruise and other recent Geosciences213 Azur expeditions allow to distinguish three distinct areas in the Central Nile Province, 214 which are described briefly below (Fig. 1; Fig. 2):

216 a) The upper slope (between $~ 500$ and 700 m water depth), characterised by the presence 217 of a few large gas chimneys (up to $4 \mathrm{~km}$ in diameter) corresponding to the leakage of gas218 rich fluids from poorly sealed hydrocarbon reservoirs (e.g. North Alex; Fig. 1). 219 Numerous slides observed in deeper parts of the Central Nile Province initiate at the 
220 location of the gas chimneys (Loncke et al., 2004). Note that one Nautile dive took place

221 in this area (i.e. North Alex chimney) during the Nautinil cruise, but those results are

222 discussed elsewhere (Dupré et al., 2007).

223

224 b) The middle slope (between $~ 700$ and $1650 \mathrm{~m}$ water depth), characterised by a series 225 of transparent acoustic bodies (debris-flow deposits) overlapping surface sediments in the 226 lower slope (Fig. 2A). The most recent debris-flow deposits in this area are overlain by a 227 thin hemipelagic cover $(\sim 0.5 \mathrm{~m})$, which suggests recent deposition. Ship-borne 228 multibeam backscatter imagery reveals the presence of a few highly reflective patches in 229 this area (Loncke et al., 2004).

231 c) The lower slope (between 1650 and 2200 m water depth), characterised by rough 232 and chaotic seafloor morphology. The sedimentary cover is deformed by repeated 233 undulations (i.e. a succession of elongated ridges and troughs), between 300 to $1500 \mathrm{~m}$ 234 wide, sub-parallel to the slope (Figs. 1, 2A,C). Loncke et al. (2002) interpreted those 235 undulations as a result of creep and gliding processes, rather than sediment waves created 236 by bottom currents. Examination of $3.5 \mathrm{kHz}$ profiles (Fig. 2A; Loncke et al., 2002) also 237 suggests that some ridges observed in this area correspond to small rotated blocks. This 238 deformed sedimentary cover is about 10 to $50 \mathrm{~m}$ thick and is underlain by debris-flow 239 deposits (Fig. 2A). In core NLK11 (see location in Fig. 1), debris-flow deposits occur at 240 sediment depths below $12 \mathrm{~m}$ (Fig. 5). A large number of highly reflective patches were 241 identified in this area (Loncke et al., 2004), some of which were investigated during the 242 Nautinil cruise (Figs. 1 and 2). 
244 4.2. Fluid venting structures

245 Microbathymetric profiles and maps for sediment facies and carbonate crust occurrences

246 along each Nautile dive transect are shown in Figures 3 and 4, together with EM-300

247 Multibeam acoustic map (Fig. 3A) and side-scan sonar seafloor imagery (Fig. 4). Note

248 that only the dive NL7 area (middle slope area) was surveyed by the EdgeTech deep tow

249 sonar during the Mimes expedition. Combining geophysical data, in situ observation and

250 microbathymetric profiles, four types of fluid venting structures can be identified in the

251 lower slope and middle slope parts of the Central Nile province, which are described 252 below.

254 4.2.1. Carbonate ridges (lower slope)

255 Three carbonate-paved areas were discovered on the lower slope during the Nautile 256 dives, which correspond clearly to highly reflective patches (dark spots) on EM-300 257 multibeam mosaic (Fig. 3A). Microbathymetric profiles generated from the submersible 258 sensors reveal that they correspond to aligned carbonate mounds, up to $\sim 500 \mathrm{~m}$ long and $2595 \mathrm{~m}$ high (Fig. 3B,C). Clearly, these carbonate-paved areas occur on top of the elongated 260 ridges related to downslope mass movements (Fig. 2). Carbonate pavements were mainly 261 covered by hemipelagic sediments (Fig. 6A). Fractured carbonate pavements were 262 observed typically in topographically steep areas (Fig. 3B; Fig. 6B,C), often associated to 263 faults with orientations N70 and N160.

265 4.2.2. Elongated sediment depressions or troughs (lower slope) 
266 In situ observations show the occurrence of large elongated depressions ( 100 m long; 3

267 m deep) with signs of intense bioactivity, which occur in the immediate vicinity of

268 carbonate ridges. The bioactivity is documented by the presence of light grey shell-rich

269 sediments associated with numerous bioturbation mounds (Fig. 6G). Those depressions

270 correspond to those slope-parallel troughs associated with undulations (Fig. 2), identified

271 previously on multibeam bathymetric maps (Loncke et al., 2004). During the Nautile

272 dives, many faults were observed in sediments (Fig. 3; Fig. 6H), with directions parallel

273 ( N70) or perpendicular ( N160) to the slope (Fig. 3).

275 4.2.3. Other carbonate-paved areas (middle slope)

276 Two large $\left(\sim 1 \mathrm{~km}^{2}\right)$ carbonate-paved areas with irregular shapes and partly covered by 277 sediments were identified from the side-scan sonar data in the middle slope (i.e. the large 278 high backscatter areas shown as white patches in Fig. 4). The southernmost edge of one 279 of these structures was visited during Nautile dive NL7 (Fig. 4), which corresponds to 280 unfractured massive carbonate pavements. Bathymetric data acquired during the Nautile 281 dive did not provide any evidence of topographic irregularities associated with carbonate 282 pavements at that location.

284 4.2.4. Pockmarks

285 Numerous pockmarks were observed during the Nautile dives, both in the lower and

286 middle slope areas. Pockmarks correspond to sub-circular depressions on the seafloor of 287 variable size (typically 3-20 m across and up to $3 \mathrm{~m}$ deep), which can be isolated or occur 288 as clusters (Figs. 4 and 6E). In the lower slope, pockmarks were observed in close 
289 vicinity to troughs (Fig. 3). Authigenic carbonate crusts occur typically in the central part 290 of pockmarks, forming in some cases chimney-like build-ups (Fig. 6F). Shell debris,

291 authigenic carbonate crusts and infilled burrows often accumulate within the depressions

292 (Fig. 6F). In contrast to the reddish-brown foraminiferal and pteropod oozes 293 characterising hemipelagic sediments on the Nile deep-sea fan (see reference core; Fig. 294 5), dark grey sediments were observed frequently in pockmarks (pushcore NL6-PC1; Fig. 295 5).

4.3. Biological observations

298 Several animal communities were observed during the Nautile dives in the two studied 299 areas. Vestimentiferan tubeworms (Polychaeta: Siboglinidae) were often present in close 300 association with carbonate crusts (Fig. 7), both in pockmarks and carbonate-paved areas. 301 Two morphotypes of siboglinids were distinguished after examination of photographs 302 and videos collected during the dives, but only one of them (assigned to the genus 303 Lamellibrachia; Webb, 1969) was sampled successfully (Fig. 7A).

304 Numerous small mussels (length $<\sim 1 \mathrm{~cm}$ ) were found on carbonate crusts and 305 associated sediments, occurring frequently inside small cavities within carbonate 306 deposits. Those mussels have been shown recently to harbour 6 distinct types of bacterial 307 symbionts, including sulphur- and methane-oxidizing bacteria, a diversity larger than 308 reported from any other bivalve to date (Duperron et al, 2008). They display 309 morphological similarities to Idas modiolaeformis (Sturany, 1896), a species reported at 310 other eastern Mediterranean cold seep sites (Olu-Le Roy et al., 2004). Additional fauna 311 associated with crusts includes anemones, serpulid polychetes and small galatheid crabs. 
312 Empty bivalve shells were observed in carbonate-paved areas and pockmarks, but also in

313 those large depressions close to carbonate ridges (P. Briand \& K. Olu-Le Roy, pers.

314 com.). These shells are similar to shells of Isorropodon perplexum (Vesycomyidae) and

315 Thyasira striata (Thyasiridae), reported previously in the Nile deep-sea fan (Sturany, 316 1896) and on Anaximander mud volcanoes (Olu-Le Roy et al. 2004). A few living 317 specimens of lucinids were sampled, which exhibit close morphological similarities to 318 Lucinoma kazani (Anaximander mud volcanoes; Salas and Woodside 2002) and Myrtea 319 amorpha (Mediterranean Ridge cold seeps; Olu-Le Roy et al. 2004). The former were 320 shown recently to harbour sulphur-oxidizing bacteria (Duperron et al, 2007).

\section{4.4. Detection of gas seeps}

323 Methane profiles acquired in the lower slope with the Capsum METS sensor along 324 selected dive transects are shown in Figs. 3B and C. Significant methane anomalies were 325 measured in bottom waters above the large depressions associated with bioturbation 326 mounds. Clearly, this shows that those troughs correspond to active sites of methane 327 seepage. In contrast, no (dives NL6) or weak (dive NL14) methane anomalies were 328 detected above carbonate-paved areas (Figs. 3B and C). In the middle slope, the Capsum 329 sensor did not detect any methane anomaly (not shown here), but evidence for active 330 fluid seepage is suggested by acoustic anomalies of side-scan sonar records of the water 331 column attributed to gas bubbles (S. Dupré, personal communication; not shown here). 332 One such acoustic gas anomaly was identified in close proximity to those large carbonate 333 structures with irregular shapes. 
334 At pockmarks, seepage of methane-rich fluids was inferred frequently by the presence

335 of dark grey sediments (e.g. indicating the presence of an abundant organic fraction not

336 decomposed). Evidence for on-going anaerobic oxidation of methane and bacterial

337 sulphate reduction in one of those pockmarks was also given by a strong $\mathrm{H}_{2} \mathrm{~S}$ smell upon

338 opening of core NL6-PC1 (Fig. 5).

340 4.5. Pore water and sediment geochemistry

341 Down-core high resolution profiles of $\mathrm{CaO}$ (wt. \%), reduced and oxidized sulfur (wt.

$342 \%)$ and barium (ppm) contents in sediment from push-cores NL14-PC1 and NL14-PC3

343 are presented in Fig. 8. Dissolved sulphate concentrations in pore waters (for core NL14-

344 PC1 only) are also reported in Fig. 8. Pore water $\mathrm{SO}_{4}{ }^{2-}$ concentrations are quasi-constant

345 down to $\sim 17 \mathrm{~cm}$ depth, with values $(\sim 30 \mathrm{mM})$ close to seawater concentrations.

346 In contrast to dissolved $\mathrm{SO}_{4}{ }^{2-}$ concentrations, $\mathrm{S}$ concentrations in solid sediment

347 phases increase from just a few centimeters $(\sim 7 \mathrm{~cm})$ below the sediment/water interface

348 (Fig. 8). In core NL14-PC1, enrichments of Ba and reduced S are related to the presence

349 of barite (barium sulphate) and pyrite (iron sulfide), respectively. Mineralogical analyses

350 and microscope observations reveal that authigenic gypsum (calcium sulphate) is also

351 present within sediments.

4.6. Carbonate ${ }^{230} \mathrm{Th} / \mathrm{U}$ ages

354 U-Th data for the two carbonate crusts analysed are listed in Table 2. Only one 355 meaningful age was obtained for those lithified carbonate samples collected on the 356 carbonate ridges (Table 2). This is due to an important ${ }^{230}$ Th detrital contamination in 
357 those clay-rich samples. The calculated age for sample NL14-CC5 is $7.9 \pm 1.4 \mathrm{ka}$ 358 (Table 2).

\section{5 - Discussion}

361 5.1. Deformation style in the Central Nile margin

362 Significant differences were observed between the lower slope and the middle slope, 363 which are summarised in Table 3. In the lower slope, downslope mass movements lead 364 to formation of elongated ridges and troughs parallel to the slope (Loncke et al., 2002).

365 Observation of numerous fractures in sediments during the Nautile dives provides direct 366 evidence that active mass gravity processes occur in the lower slope. The presence of 367 similar ridges and troughs at the base of continental margins has been extensively 368 described in the literature (e.g. Mulder and Cochonat, 1996; van Weering et al., 1998; 369 Lee and Chough, 2001; Gay et al., 2004). In the case of creep and downslope gliding, 370 gravitational processes create typically two distinct structural domains: an extensional 371 domain in the upper slope and a compressive domain located downslope (e.g. Allen, 372 1985; Pickering et al., 1989; Stow, 1994). In most cases, ridges and troughs form in the 373 distal compressive parts of creeping or gliding sediment masses. By analogy, the lower 374 slope on the Central Nile deep-sea fan could also correspond to a regional compressive 375 domain. However, the occurrence of small rotated blocks in the lower slope indicates 376 that extensional deformation takes place instead in this area, leading to faulting and 377 associated rotated blocks. Most probably, it is likely that creeping of surface sediments 378 in this lower slope domain also induces local compression, which could contribute, at 379 least to some extent, to the formation of ridges and troughs. 
380 In contrast to the lower slope, there is no direct evidence for active deformation 381 processes taking place in the middle slope area. Most probably, the evidence that debris382 flow deposits accumulated in the middle slope overlap surface sediments in the lower 383 slope indicates that those two domains are decoupled.

\subsection{Temporal evolution of fluid circulation}

In cold seep environments, reduction of sulphate in pore waters is closely related to 387 methane oxidation (Niewöhner et al., 1998; Borowski et al., 1999). The depth at which 388 sulphate reduction occurs in sediments is controlled primarily by the upward flux of 389 methane, being closer to the seafloor for high methane fluxes (Niewöhner et al., 1998; 390 Borowski et al., 1999). Information on the temporal evolution of fluid venting at any site 391 can be obtained by comparing pore water data (which give information on present-day 392 fluid circulation) and solid sediment geochemical data (which may provide an integrated 393 record of fluid seepage over the last few thousand years). In core NL14-PC1, the 394 constant dissolved sulphate profile indicates that sulphate reduction does not proceed in 395 the top sediment layer $(\sim 0-20 \mathrm{~cm})$ at present. This suggests that methane-rich fluids 396 probably do not circulate in sub-surface sediments at this location.

397 In contrast, the presence of authigenic sulphate (oxidized S) and sulfide (reduced S) 398 minerals within sediment cores collected at carbonate ridges implies that reduction of 399 pore-water sulphate was active at these sediment depths in the recent past. The dark grey 400 sulfur- and barium-rich sediment layer in cores NL14-PC1/3 probably does not 401 correspond to the Holocene Sapropel layer S1 (e.g., Olausson, 1961), which is buried at 402 deeper sediment depths in the studied area $(>15 \mathrm{~cm}$ in our reference push-core NL7- 
BC1; Fig. 5). The occurrence of S-rich minerals in NL14-PC1/3 sediments is probably

404 related to oxidation of methane-rich fluids at that location in the recent past. At present, 405 cold seep settings where sulphate reduction proceeds at only a few centimeters below the 406 seafloor correspond to sites characterized by active fluid advection (e.g. see Haese et al., 4072003 and references therein).

408 Absolute dating of authigenic carbonates with U-series also provides a means for 409 reconstructing the evolution of cold seeps and associated fluid circulation through time 410 (Teichert et al., 2003; Bayon et al., 2007). Certainly, additional U-Th isotope 411 measurements would be needed to better constrain any spatial and temporal variations of 412 fluid circulation activity in the lower slope. However, the U-Th age ( 8 kyr BP) 413 calculated for crust NL14-CC5 suggests that carbonate precipitation and hence fluid 414 seepage was active at the studied carbonate ridge in the early Holocene. Taken together, 415 our U-Th data and sediment geochemical profiles suggest therefore that the activity of 416 fluid venting at carbonate ridge locations may have decreased over a recent period.

418 5.3. The origin of fluids

419 Fluids expelled at cold seeps on the Nile deep-sea fan may derive from shallow and/or 420 deep sediment sources. Potential deep fluid sources include messinian and pre-messinian 421 thermogenic hydrocarbon reservoirs (Abdel Aal et al., 2000; Samuel et al., 2003; Loncke 422 et al., 2004). During the Nautinil expedition, the discovery of brine lakes on the seafloor 423 (Menes Caldera, Western Nile province; Huguen et al., in revision) has provided clear 424 evidence that fluids passing through or originating from deep evaporite deposits could be 425 emitted on the seafloor in the Nile Delta area. Shallow fluid sources at cold seeps are 
most often related to formation of biogenic methane in superficial sediment layers; a

427 consequence of the microbial degradation of organic matter during early diagenetic

428 processes. Several organic-rich sediment layers (sapropels) have accumulated in Eastern

429 Mediterranean basins during the Late Quaternary period (e.g., Olausson, 1961; De Lange

430 and Ten Haven, 1983; Rossignol-Strick et al., 1982), which represent potential sources of

431 methane-rich fluids to cold seeps in the Nile deep sea fan area. Fine-grained turbidites

432 deposited on the deep-sea fan during the Late Quaternary may represent an additional

433 source of biogenic methane. None of the data presented in this study can be used to

434 discriminate the origin of fluids in the Central Nile area. However, stable isotope 435 measurements $\left(\delta^{13} \mathrm{C}\right.$ and $\left.\delta^{18} \mathrm{O}\right)$ on authigenic crusts collected during the Nautinil 436 expedition (Gontharet et al., 2007) suggest that the fossil carbon source involved in 437 carbonate precipitation in this area derives from biogenic methane primarily (i.e. a 438 shallow source).

440 5.4. Formation mode of fluid-escape structures and links with sediment deformation

$441 \quad$ 5.4.1. Lower slope

442 One major result of this study is the close relationship between slope parallel elongated 443 ridges/troughs and the occurrence of fluid-escape structures (see Fig. 9; Table 3). In the 444 lower slope, carbonate-paved areas are located clearly on top of ridges, whereas methane 445 venting occurs above troughs (Fig. 9). It is very likely that gravity processes and 446 deformation in the lower slope have created preferential pathways for fluid migration and 447 gas escape. The large depressions or troughs, characterized by intense bioactivity and 448 active methane venting, corresponds most probably to the present-day seafloor 
449 expression of those preferential pathways (e.g. faults) related to sediment deformation

450 (Fig. 9). Pockmarks observed in close vicinity to the troughs could form from excess

451 volumes of fluids periodically migrating upslope from the troughs, possibly aided by the

452 creation of migration pathways along fractures (Fig. 9).

453 At present, it is likely that carbonate precipitation occurs within sediments in those 454 depressions associated to active methane venting. Instead, we propose that carbonate 455 pavements emplaced on top of ridges were outcropped on the seafloor in response to 456 sediment instability, after initial formation of carbonate crusts. The exposure of those 457 carbonate pavements could be due either to compressional deformation as pressure ridges 458 or, alternatively, be related to faulting associated with the rotated blocks. This 459 exhumation process would be in agreement with the presence of intensively fractured 460 carbonate crusts on top of those ridges. Carbonate ridges would hence correspond to 461 'paleo-troughs' (i.e. ancient sites of active fluid venting). Our geochemical results 462 suggest that fluid seepage at those ridges has decreased most probably since the early 463 Holocene (see section 5.2). Most likely, this indicates that slope instability may induce a 464 change in fluid flow conditions at any given location; from focused flow to diffuse flow 465 for the case of those carbonate ridges. The persistence of seep habitats on top of ridges at 466 present would hence be related to pervasive microseepage only.

468 Other carbonate ridges were discovered recently on the continental slope off Norway 469 (Hovland et al., 2005), though in a different geological setting (e.g. proximity to gas 470 hydrate reservoirs). Hovland et al. (2005) proposed that such ridges were formed during 471 catastrophic fluid-flow events, in response to abrupt breaking of carbonate seals above 
472 preferential fluid pathways. In the Central Nile province, however, observation that 473 carbonate ridges occur only on one side of those large sediment depressions (see 474 bathymetric profile in Figs. 3B and C) argues against such a formation by catastrophic 475 fluid flow event. Therefore, our preferred explanations remain that: 1) fluid migration is 476 controlled by slope instability in the lower slope, and 2) sediment gliding is responsible 477 for formation of carbonate ridges.

479 During the last few hundred thousand years, sediment mass-wasting has been active in 480 the Nile deep sea fan, leading to deposition of a series of debris-flows and turbidites 481 (Ducassou et al., 2007). It is likely that sediment accumulation on the middle and lower 482 slopes has led, to some extent, to compaction/dewatering in sub-surface sediments, 483 generating ultimately excess pore water pressure and fluid migration. Investigation of 484 core NLK11 shows that sediments deposited above those debris-flow deposits (i.e. the 485 top $12 \mathrm{~m}$ of core NLK11) exhibit vertical pipes filled with fluidised sediments, which 486 correspond to fluid migration structures (Fig. 5). In contrast, sediments associated with 487 debris-flow deposits are highly compacted. One hypothesis would be that the upper 488 surface of debris-flow deposits act as a décollement layer, along which fluids would 489 migrate preferentially. The presence of such a décollement layer at a few meters below 490 the seafloor would favour both sediment instabilities (i.e. creeping) and fluid seepage in 491 the lower slope (Fig. 9).

493 5.4.2. Middle slope 
494 Significant differences in e.g. surface, morphology, fracturation have been observed 495 between carbonate-paved areas from the lower and middle slopes (see section 4.2), 496 indicating that they were formed most probably through distinct processes. U/Th isotope 497 ages calculated on authigenic carbonates recovered from the middle slope (Bayon et al., 498 2007) showed that fluid emission in this area (at least in that carbonate-paved area 499 explored during dive NL7) has remained active for the last 5,000 years at least. This 500 suggests that the middle slope has remained stable (i.e. no major slope instability) during

501 that period. In contrast with the lower slope, the absence of any significant preferential 502 conduits and/or faulting within surface sediments in this area may provide possibilities 503 for broad diffusive, perhaps not focused, but permanent fluid venting through time.

\section{5. Conclusions}

507 Fluid venting is active on the Central Nile margin, as demonstrated by the observation 508 of fluid-related structures (pockmarks, carbonate pavements), abundant associated 509 chemosynthetic communities and the detection of bottom-water methane anomalies.

510 Detailed investigations of cold seeps from two distinct areas in the Central Nile province 511 indicate a link between fluid seepage and sediment instability.

512 The lower slope from $1650 \mathrm{~m}$ to $2200 \mathrm{~m}$ water depth is a zone of regional sediment

513 creeping, where active gravitational processes create a series of elongated slope-parallel

514 ridges and depressions. Fossil carbonate ridges up to $5 \mathrm{~m}$ high occur on top of those 515 slope-parallel ridges, whereas the deep depressions correspond to areas of active fluid 516 flow. The middle slope from $700 \mathrm{~m}$ to $1650 \mathrm{~m}$ water depth corresponds to an area 
517 recently covered by debris flow deposits, which overlap surface sediments in the lower

518 slope. In contrast with the lower slope, it shows no signs of sediment creeping, but

519 exhibits large patchy areas $\left(\sim 1 \mathrm{~km}^{2}\right)$ of carbonate pavements associated to broad and 520 more diffuse fluid flow.

521 We propose that sediment instability in the lower slope area creates preferential 522 pathways for focused fluid flow and leads to the exposure of carbonate ridges. Evidence 523 that debris-flow deposits buried under the destabilized sedimentary cover in this area are

524 highly compacted may suggest that the top of this debris-flow unit acts as a décollement 525 layer, along which fluids would migrate preferentially and, in turn, favor sediment 526 gliding. Overall, our results have general implications for understanding the processes 527 controlling methane fluxes at continental margins, and how slope instability may 528 contribute to methane release into the water column.

\section{Acknowledgements}

532 We thank the Captains, the officers and crews of R/V Atalante and R/V Pelagia, the 533 pilots and technicians of Nautile, and members of the Nautinil and Mimes scientific 534 parties for their assistance at sea. We are grateful to P. Briand (Ifremer) for his help in 535 identifying biological specimens. A. Mason (U. Oxford) is thanked for assistance during 536 U/Th analyses. Two anonymous reviewers are thanked for their comments and 537 suggestions. The Nautinil and Mimes expeditions were funded by IFREMER and the 538 Netherlands Organization for Scientific research (NWO), respectively, as part of the 539 MEDIFLUX Project (EUROMARGINS-ESF programme). 
541 Abdel Aal, A., El Barkooky, A., Gerrits, M., Meyer, H., Schwander, M., Zaki, H.A., 542 2000. Tectonic evolution of the Eastern Mediterranean basin and its significance for 543 hydrocarbon prospectivity in the ultradeepwater of the Nile delta. The Leading Edge, $544 \quad 1086-1102$.

545 Allen, J.R.L., 1985. Principles of physical sedimentology. Allen and Unwin, London, 272 $546 \quad$ pp.

547 Bayon, G., Henderson, G.M., Bohn, M., Gontharet, S., Pierre, C., 2007. U-Th 548 stratigraphy of a cold seep carbonate crust. Geochim. Cosmochim. Acta 71, 15, $549 \quad$ Supplement 1, A68-A68.

550 Bellaiche, G., Loncke, L., Gaullier, V., Mascle, J., Courp, T., Moreau, A., Radan, S., 551 Sardou, O., 2001. Le cône sous-marin du Nil et son réseau de chenaux profonds: 552 Nouveaux résultats (campagne Fanil). C. Rd. Ac. Sci., Paris 333, 399-404.

553 Borowski, W. S., Paull, C. K., Ussler III, W., 1999. Global and local variations of 554 interstitial sulphate gradients in deep-water, continental margin sediments: Sensitivity 555 to underlying methane and gas hydrates. Mar. Geol. 159, 131-154.

556 Bourdon, B., Henderson, G. M., Lundstrom, C. C., Turner, S. P., 2003. Uranium-series 557 geochemistry. Rev. Min. Geochem. 52, 656 pp.

558 de Lange, G.J., Ten Haven, H.L., 1983. Recent sapropel formation in the eastern $559 \quad$ Mediterranean. Nature 305, 797-798.

560 Dimitrov, L., Woodside, J., 2003. Deep sea pockmarks environments in the eastern $561 \quad$ Mediterranean. Mar. Geol. 195, 263-276. 
Ducassou, E., Capotondi, L., Murat, A., Bernasconi, S. M., Mulder, T., Gonthier, E., Migeon, S., Duprat, J., Giraudeau, J., Mascle, J., 2007. Multiproxy Late Quaternary stratigraphy of the Nile deep-sea turbidite system — Towards a chronology of deepsea terrigeneous system. Sedim. Geol. 200, 1-13.

Duperron, S., Fiala-Médioni, A., Caprais, J.-C., Olu, K., Sibuet, M., 2007. Evidence for chemoautotrophic symbiosis in a Mediterranean cold seep clam (Bivalvia: Lucinidae): comparative sequence analysis of bacterial 16S rRNA, APS reductase and RubisCO genes. FEMS Microbiol. Ecol. 59, 64-70.

Duperron, S., Halary, S., Lorion, J., Sibuet, M., Gaill, F., 2008. Unexpected co occurrence of 6 bacterial symbionts in the gill of the cold seep mussel Idas sp. (Bivalvia: Mytilidae). Environ. Microbiol. 10(2), 433-445.

Dupré, S., Woodside, J., Foucher, J.-P., de Lange, G., Mascle, J., Boetius, A., Mastalerz, V., Stadnitskaia, A., Ondreas, H., Huguen, C., Caprais, J.-C., Gontharet, S., Loncke, L., Deville, E., Niemann, H., Fiala-Medioni, A., Dählmann, A., Prinzhofer, A., Sibuet, M., Pierre, C., Sinninghe Damsté, J., 2007. Seafloor geological studies above active gas chimneys off Egypt (Central Nile Deep Sea Fan). Deep-Sea Res. I 54, 1146-1172.

Gaullier, V., Mart, Y., Bellaiche, G., Mascle, J., Vendeville, B., Zitter, T., the Prismed Scientific Party, 2000. Salt tectonics in and around the Nile deep sea fan : insights from the Prismed II cruise. In: Vendeville, B., Mart, Y., Vigeresse, J.L. (eds.) Salt, Shale and Igneous diapirs in and around Europe. Geological Society, London, Spec. Pub. 174, 110-129. 
584 Gay, A., Lopez, M., Cochonat, P., Sermondadaz, G., 2004. Polygonal faults-troughs system related to early stages of compaction-Upper Miocene to present sediments of the Lower Congo Basin. Basin Res. 16, 101-116.

587 Gay, A., Lopez, M., Cochonat, P., Séranne, M., Levaché, D., Sermondadaz, G., 2006.

588 Isolated seafloor pockmarks linked to BSRs, fluid chimneys, polygonal faults and 589 stacked Oligocene-Miocene turbiditic palaeochannels in the Lower Congo Basin. $590 \quad$ Mar. Geol. 226, 25-40.

591 Gontharet, S., Pierre, C., Blanc-Valleron, M.M., Rouchy, J.M., Fouquet, Y., Bayon, G., 592 Foucher, J.P., Woodside, J., Mascle, J., the Nautinil scientific party, 2007. Nature and 593 origin of the diagenetic carbonate crusts and concretions from mud volcanoes and 594 pockmarks of the Nile deep-sea fan (eastern Mediterranean sea). Deep-Sea Res. II $595 \quad 54,1291-1316$.

596 Haese, R. R., Meile, C., van Cappellen, P., de Lange, G. J., 2003. Carbon geochemistry 597 of cold seeps: Methane fluxes and transformation in sediments from Kazan mud 598 volcano, eastern Mediterranean Sea. Earth Planet. Sci. Let. 212, 361-375.

599 Hovland, M., Judd, A.G., 1988. Seabed Pockmarks and Seepages: Impact on Geology, 600 Biology and Marine Environment vol. 293, Graham and Trotman, London, 565 pp. 601 Hovland, M., Gardner, J.V., Judd, A.G., 2002. The significance of pockmarks to 602 understanding fluid flow processes and geohazards. Geofluids 2, 127-136.

603 Hovland, M., Svensen, H., Forsberg, C.F., Johansen, H., Fichler, C., Fosså, J.H., Jonsson, 604 R., Rueslåtten, H., 2005. Complex pockmarks with carbonate-ridges off mid-Norway: 605 Products of sediment degassing. Mar. Geol. 218, 191-206. 
606

607

608

609

610

Huguen, C., Foucher, J.-P., Mascle, J., Ondreas, H., Thouement, M., Gontharet, S., Stadnitskaia, A., Pierre, C., Bayon, G., Loncke, L., Boetius, A., Bouloubassi, I., de Lange, G., Caprais, J.-C., Fouquet, Y., Woodside, J., and the NAUTINIL Scientific Party, 2008. Menes Caldera, a highly active site of brine seepage in the Eastern Mediterranean Sea: “in situ” observations from the Nautinil expedition (2003). Marine Geology (EUROMARGINS Special Issue, This volume).

Judd, A.G., Hovland, M., 2007. Seabed Fluid Flow, the impact on geology, biology and the marine environment. Cambridge University Press, 475 pp.

Kennett, J. P., Cannariato, K. G., Hendy, I. L., Behl, R. J., 2002. Methane hydrates in quaternary climate change: the clathrate gun hypothesis. Am. Geophys. Union, 216 pp.

Lastras, G., Canals, M., Urgeles, R., Hughes-Clarke, J.-E., Acosta, J., 2004. Shallow slides and pockmark swarms in the Eivissia Channel, western Mediterranean Sea. Sedimentology 51, 1-14.

Lee, S.H., Chough, S.K., 2001. High-resolution $(2 \pm 7 \mathrm{kHz})$ acoustic and geometric characters of submarine creep deposits in the South Korea Plateau, East Sea. Sedimentology 48, 629-644.

Loncke, L., Gaullier, V., Bellaiche, G. and Mascle, J., 2002. Recent depositional patterns of the Nile Deep-Sea Fan from echo-character mapping. AAPG Bull. 86, 1165-1186.

Loncke, L., Mascle, J., Fanil Science Party, 2004. Mud volcanoes, gas chimneys pockmarks and ridges in the Nile deep-sea fan (Eastern Mediterranean): geophysical evidences. Mar. Petrol. Geol. 21, 669-689. 
628 Loncke, L., Gaullier, V., Mascle, J., Vendeville, B., Camera, L., 2006. The Nile deep-sea 629 fan : An example of interacting sedimentation, salt tectonics, and inherited subsalt 630 paleotopographic features. Mar. Petrol. Geol. 23, 297-315.

631 Mascle, J., Benkhelil, J., Bellaiche, G., Zitter, T., Woodside, J., Loncke, L. and Prismed 632 II scientific party, 2000. Marine geological evidence for a Levantine-Sinai plate, a 633 missing piece of the Mediterranean puzzle. Geology 28, 779-782.

634 Maslin, M.A., Owen, M., Day, S., Long, D., 2004. Linking continental slope failure to 635 climate change: Testing the Clathrate Gun Hypothesis. Geology 32, 53-56.

636 Mienert, J., 2004. COSTA—continental slope stability: major aims and topics. Mar. $637 \quad$ Geol. 213, 1-7.

638 Mienert, J., Vanneste, M., Bünz, S., Andreassen, K., Haflidason, H., Sejrup, H.P., 2005. 639 Ocean warming and gas hydrate stability on the mid-Norwegian margin at the 640 Storegga Slide. Mar. Petrol. Geol. 22, 233-244

641 Mulder, T., Cochonat, P., 1996. Classification of offshore mass movements. J. Sedim. $642 \quad$ Res. 66, 43-57.

643 Niewöhner, C., Hensen, C., Kasten, S., Zabel, M., Schulz, H. D., 1998. Deep sulphate 644 reduction completely mediated by anaerobic methane oxidation in sediments of the 645 upwelling area off Namibia. Geochim. Cosmochim. Acta 62, 455-464.

646 Nisbet, E.G., 2002. Have sudden large releases of methane from geological reservoirs 647 occurred since the Last Glacial Maximum, and could such releases occur again? Phil. $648 \quad$ Trans. R. Soc. Lond. A 360, 581-607.

649 Olausson, E., 1961. Studies of deep sea cores. Reports of Swedish Deep-Sea expeditions $650 \quad$ 1947-1948, 8, 336-391. 
651 Olu-Le Roy, K., Sibuet, M., Fiala-Médioni, A., Gofas, S., Salas, C., Mariotti, A., 652 Foucher, J.P., Woodside, J., 2004. Cold seep communities in the deep eastern 653 Mediterranean Sea: composition, symbiosis and spatial distribution on mud 654 volcanoes. Deep-Sea Res. I 51, 1915-1936.

655 Paull, C.K., Ussler III, W., Dillon, W.P., 2000. Potential role of gas hydrate 656 decomposition in generating submarine slope failures. In: Max, M.D. (Ed.), Natural 657 Gas Hydrate in Oceanic and Permafrost Environments, Kleuwer Acad. Publishers, 658 Dordrecht, 149-156.

659 Paull, C., Ussler III, W., Maher, N., Greene, H.G., Rehder, G., Lorenson, T., Lee, H., 660 2002. Pockmarks off Big Sur, California. Mar. Geol. 181, 323-335.

661 Pickering, K.T., Hiscott, R.N., and Hein, F.J., 1989. Deep marine environments. Harper662 Collins, London, 416 pp.

663 Rossignol-Strick, M., Nesteroff, W.D., Olive, P., Vergnaud-Grazzini C., 1982. After the 664 deluge: Mediterranean stagnation and sapropel formation. Nature 295, 105-110.

665 Salas, C., Woodside, J., 2002. Lucinoma kazani n. sp. (Mollusca: Bivalvia): evidence of 666 a living benthic community associated with a cold seep in the Eastern Mediterranean 667 Sea. Deep-Sea Res. I 49, 991-1005.

668 Salem, R., 1976. Evolution of Eocene-Miocene sedimentation patterns in parts of 669 Northern Egypt. AAPG Bull. 60, 34-64.

670 Samuel, A., Kneller, B., Raslan, S., Sharp, A. and Parsons, C., 2003. Prolific deep-marine 671 slope channels of the Nile delta, Egypt. AAPG Bull. 87, 541-560.

672 Sardou, O., Mascle, J., 2003. Cartography by multibeam echo-sounder of the Nile deep673 sea Fan and surrounding areas (2 sheets). Special publication CIESM, Monaco. 
Sowers, T., 2006. Late Quaternary atmospheric CH4 isotope records suggests marine clathrates are stable. Nature 311, 838-840.

Stow, D.A.V., 1994. Deep-sea processes of sediment transport and deposition. In: Pye, K. (Ed.), Sediment Transport and Depositional Processes. Blackwell, London, pp. 257293.

Sturany, R., 1896. Zoologische Ergebnisse VII. Mollusken I (Prosobranchier und Opisthobranchier; Scaphopoden; Lamellibranchier) gesammelt von S.M. Schiff "Pola" 1890-1894. Denkschriften der Kaiserlichen Akademie der Wissenschaften, Mathematische-Naturwissenschaftlischen Classe 63, 1-36, pl.1-2.

Teichert, B. M. A., Eisenhauer, A., Bohrmann, G., Haase-Schramm, A., Bock, B., Linke, P., 2003. U/Th systematics and ages of authigenic carbonates from Hydrate Ridge, Cascadia Margin: recorders of fluid flow variations. Geochim. Cosmochim. Acta 67, 3845-3857.

Trincardi, F., Cattaneo, A., Correggiari, A., Ridente, D., 2004. Evidence of soft sediment deformation, fluid escape, sediment failure and regional weak layers within the late Quaternary mud deposits of the Adriatic Sea. Mar. Geol. 213, 91-119.

Ussler III, W., Paull, C.K., Boucher, J., Friederich, G.E., Thomas, D.J., 2003. Submarine pockmarks: a case study from Belfast Bay, Maine. Mar. Geol. 202, 175-192.

van Weering, T.C.E., Nielsen, T., Kenyon, N.H., Akentieva, A.K., Kuijpers, A. 1998. Large Submarine slides at the NE Faroe continental margin. In: Stoker, M., Evans, D., and Cramp, R. (Eds.), Geological Processes on Continental Margins: Sedimentation, Mass-Wasting and Stability. Geological Society London Special Publications 129, pp. 5-17. 
697 Vogt, P.R., Gardner, J., Crane, K., Sundvor, E., Bowles, F., Cherkashev, G., 1999. 698 Ground-truthing 11- to 12-kHz side-scan sonar imagery in the Norwegian-Greenland 699 Sea. Part I: pockmarks on the Vestnesa Ridge and Storegga slide margin. Geo Mar. $700 \quad$ Lett. 19, 97-110.

701 Webb, M., 1969. Lamellibrachia barhami gen. nov. sp. nov., (Pogonophora) from the 702 northeast Pacific. Bull. Mar. Sci. 19, 18-47. 
705 Figure 1: Bathymetric map of the Nile deep-sea fan (Sardou and Mascle, 2003) and 706 distribution of fluid-escape structures (Loncke et al., 2004) showing the two sites 707 investigated with the Nautile submersible, at $2100 \mathrm{~m}$ depth (lower slope) and $1650 \mathrm{~m}$ 708 depth (middle slope). Note the presence of elongated ridges sub-parallel to the slope 709 (direction N70) in the lower slope of the Central Province.

711 Figure 2: (A) 3.5-kHz sub-bottom profile perpendicular to the slope in the Central Nile 712 Province (see Fig. 1 for NL2-6 trackline position). (B,C) Shaded bathymetric maps of 713 the two sites investigated in the Central Nile Province with position of the Nautile 714 transects (see location of sites in Fig. 1). (B) Middle slope, dive NL7, 1650 m water 715 depth; (C) Lower slope, dives NL6 and NL14, 2100 m water depth. Note the marked 716 morphological contrast between the middle slope and the lower slope. The lower slope is 717 characterised by a rough and morphological seafloor morphology, which exhibits 718 repeated elongated ridges and depressions parallel to the slope.

720 Figure 3: Seafloor observations of fluid-escape structures in the lower slope domain.

721 (A) Multibeam seafloor acoustic imagery showing the distribution of highly reflective 722 patches (dark spots) with indication of the Nautile transects (see location of sites in Fig. 723 1). (B,C) Maps for sediment and carbonate facies, microbathymetric profiles and 724 bottom-water methane anomalies recorded along the dive transects. Fault positions and 725 sampling sites for sediment cores and carbonate crusts are also shown. 
727 Figure 4: Side-scan sonar image of the seafloor in the middle slope showing the

728 presence of large carbonate paved-areas with indication of the Nautile transect (see

729 location in Fig. 1). Sampling sites for sediment cores and carbonate crusts collected

730 during the dive are also reported.

731

732 Figure 5: Lithological description of sediment cores recovered during the submersible

733 dives. Push cores NL6-PC1, NL14-PC1 and NL14-PC3 were collected in the lower

734 slope, in fluid-venting areas (pockmark, carbonate ridges). Box core NL7-BC1 was

735 recovered in the middle slope, away from any fluid-escape structure. The location of 736 these cores is shown in Figs. 1, 3B,C, and 4.

738 Figure 6: Seafloor bottom photographs of fluid-escape structures. (A) Carbonate 739 pavements partly covered by thin sediments (carbonate ridge; lower slope). (B) Fractured 740 carbonates on a carbonate ridge (lower slope). (C) Fracture on a carbonate ridge (lower

741 slope). (D) Non fractured massive carbonate pavement (middle slope). (E) Small

742 pockmark ( $3 \mathrm{~m}$ across) in the lower slope. Note the presence of authigenic carbonates, 743 grey anoxic sediments and vestimentiferan tubeworms. (F) Large pockmark ( $25 \mathrm{~m}$ 744 across) exhibiting two carbonate chimneys and a dense network of infilled burrows 745 (middle slope). The central part of the pockmark corresponds to accumulated debris of 746 dead shells, authigenic carbonates and burrows. (G) Shell-rich sediments and bioturbation 747 mounds in one of those troughs (large seafloor depression) related to gravity tectonics 
748 (lower slope). (H) Fault in hemipelagic sediments away from fluid-escape structures

749 (lower slope). White scale bars correspond to $\sim 1 \mathrm{~m}$.

750

751 Figure 7: Vestimentiferan tubeworms associated with carbonate crusts. (A) First

752 morphotype observed, assigned preliminarily to the genus Lamellibrachia (dive NL7;

753 middle slope). (B) Second morphotype observed, but not collected (dive NL6; lower

754 slope). Note that the morphology of the chitinous tube differs from that of the first morphotype.

755 White scale bars correspond to $\sim 20 \mathrm{~cm}$.

757 Figure 8: Down-core profiles of $\mathrm{CaO}$ (wt\%), $\mathrm{S}$ oxidized (wt\%), $\mathrm{S}$ reduced (wt\%), Ba (ppm) 758 for push-cores NL14-PC1 and NL14-PC3 taken at a carbonate ridge (lower slope, see 759 location in Figs. 3B and C). Dissolved pore water $\mathrm{SO}_{4}{ }^{2-}(\mathrm{mM})$ contents are also plotted 760 for core NL14-PC1. Enrichments of oxidized/reduced sulphur and barium in solid 761 sediment phases indicate that reduction of dissolved sulphates has been active at these 762 locations in the recent past. In contrast, the flat dissolved $\mathrm{SO}_{4}{ }^{2-}$ profile, with seawater-

763 like values, shows that sulphate reduction does not take place in sub-surface sediments at 764 present.

765

766 Figure 9: Conceptual model linking fluid seepage and sediment deformation in the lower 767 slope. Active gravitational processes (creep and/or gliding) create a series of elongated 768 slope-parallel sediment ridges and depressions in the lower slope. Sediment instability 769 leads to exhumation of fractured carbonate pavements on top of ridges, which correspond 770 to 'fossil' vent sites. The exhumation of those carbonate ridges can be due either to $(27 / 05 / 08)$ 
771 compressional deformation (i.e. creep) or be related to faulting associated with rotated 772 blocks (i.e. gliding). The depressions correspond instead to preferential pathways for 773 focused fluid flow. The top of debris-flow deposits (highly compacted) buried under the 774 destabilized sediment cover could act as a décollement layer along which fluids would 775 migrate preferentially, favouring in turn sediment gliding.

776 
Table 1. Positions and water depths of the cores and carbonate crusts investigated

\begin{tabular}{clcccc}
\hline Core / Carbonate & Description & $\begin{array}{c}\text { Length } \\
(\mathrm{m})\end{array}$ & $\begin{array}{c}\text { Water depth } \\
(\mathrm{m})\end{array}$ & $\begin{array}{c}\text { Latitude } \\
\mathrm{N}\end{array}$ & $\begin{array}{c}\text { Longitude } \\
\mathrm{E}\end{array}$ \\
\hline Sediment cores & & & & & \\
NL6-PC1 & Push core & 0.36 & 2115 & $32^{\circ} 38.14^{\prime}$ & $29^{\circ} 56.12^{\prime}$ \\
NL14-PC1 & Push core & 0.35 & 2116 & $32^{\circ} 38.33^{\prime}$ & $29^{\circ} 55.80^{\prime}$ \\
NL14-PC3 & Push core & 0.25 & 2130 & $32^{\circ} 38.44^{\prime}$ & $29^{\circ} 54.98^{\prime}$ \\
NLK11 & Kullenberg & 14 & 2207 & $32^{\circ} 40.99^{\prime}$ & $29^{\circ} 54.00^{\prime}$ \\
NL7-BC1 & Blade core & 0.15 & 1623 & $32^{\circ} 30.50^{\prime}$ & $30^{\circ} 23.09^{\prime}$ \\
Carbonate crusts & & & & \\
NL6-CC1 & lithified crust & 2132 & $32^{\circ} 38.38^{\prime}$ & $29^{\circ} 54.87^{\prime}$ \\
NL14-CC5 & lithified crust & 2130 & $32^{\circ} 38.44^{\prime}$ & $29^{\circ} 54.98^{\prime}$ \\
NL7-CC2 & porous crust & 1686 & $32^{\circ} 31.61^{\prime}$ & $30^{\circ} 21.16^{\prime}$ \\
\hline
\end{tabular}


Table 2. U-Th data for authigenic carbonates

\begin{tabular}{ccccccc}
\hline Sample & $\begin{array}{c}\text { Depth } \\
(\mathrm{cm})\end{array}$ & $\begin{array}{c}{ }^{238} \mathrm{U} \\
(\mathrm{ppm})\end{array}$ & $\begin{array}{c}{ }^{230} \mathrm{Th} \\
(\mathrm{ppt})\end{array}$ & $\left({ }^{230} \mathrm{Th} /{ }^{232} \mathrm{Th}\right)$ & $\delta^{234} \mathrm{U}_{(0)}$ & $\begin{array}{c}\text { Isochron age } \\
(\mathrm{ka})\end{array}$ \\
\hline NL14-CC5 & 0.5 & $2.997 \pm 0.004$ & $28.67 \pm 0.14$ & $2.44 \pm 0.01$ & $128.7 \pm 1.7$ & - \\
' & 2 & $5.158 \pm 0.006$ & $17.15 \pm 0.04$ & $3.62 \pm 0.01$ & $144.2 \pm 1.7$ & $7.9 \pm 1.4$ \\
NL6-CC1 & 2 & $3.702 \pm 0.004$ & $35.29 \pm 0.15$ & $2.52 \pm 0.01$ & $129.3 \pm 1.7$ & - \\
\hline
\end{tabular}


Table 3. Geological setting and fluid-vent structures in the lower and middle slope

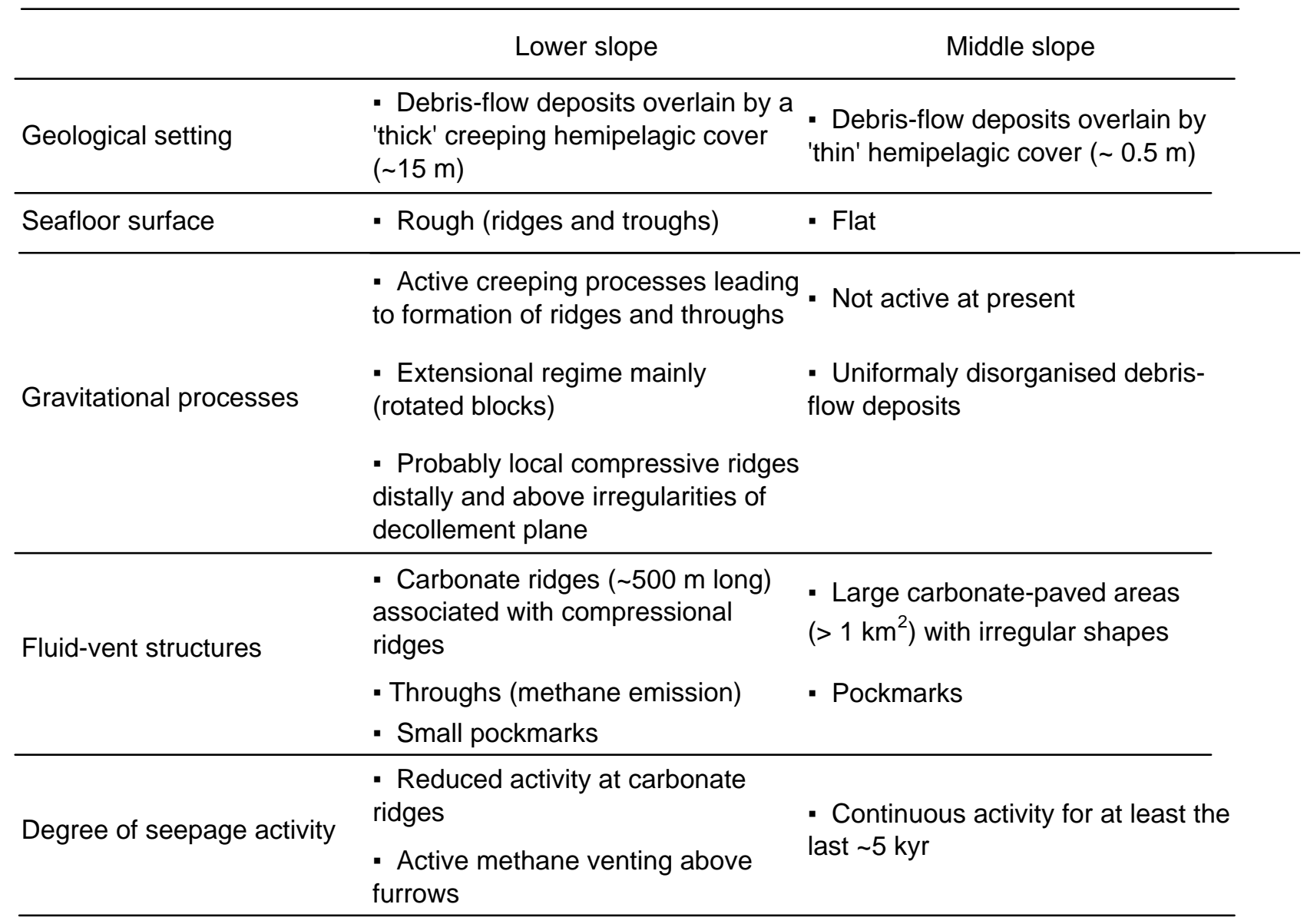




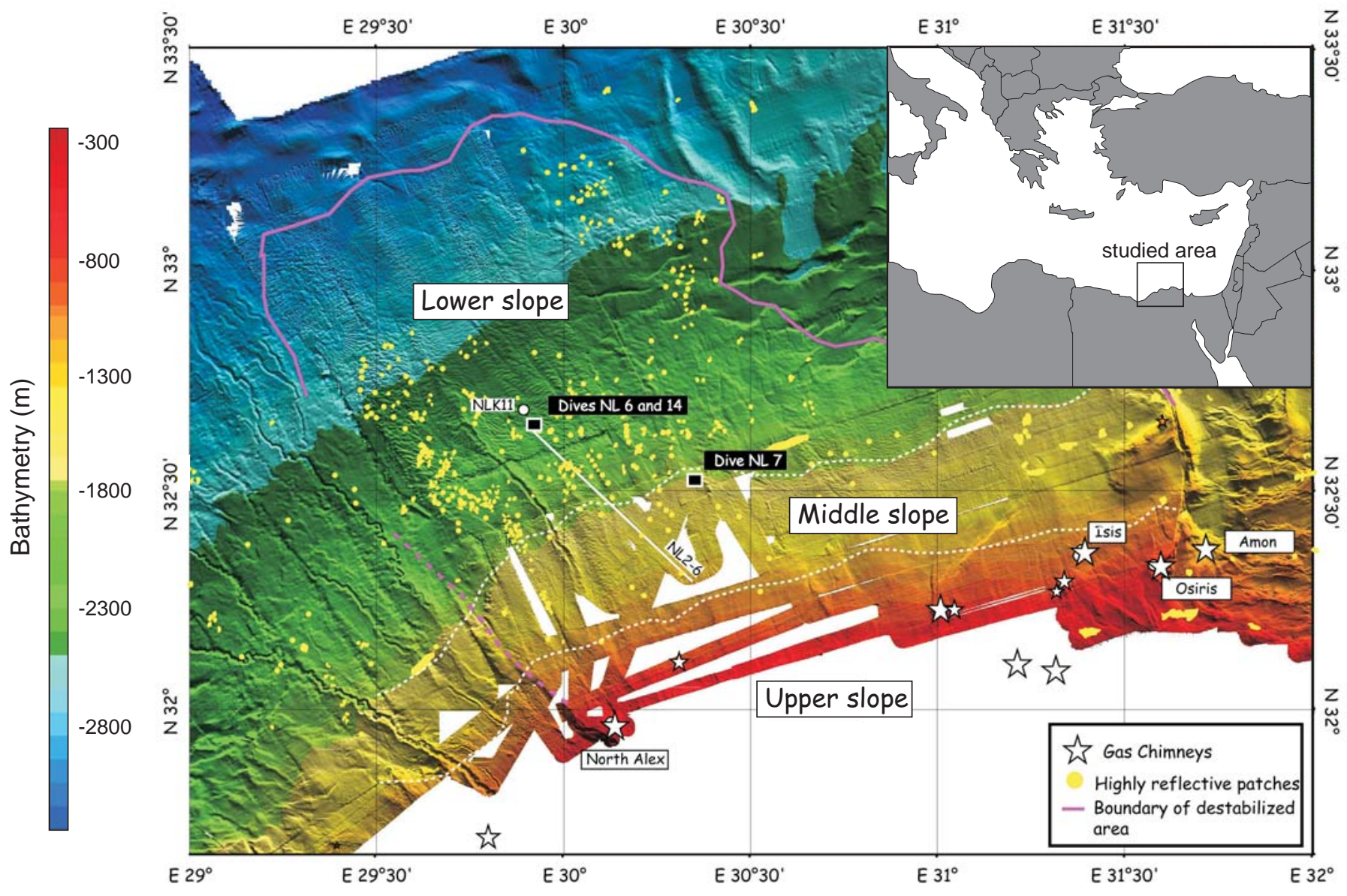

Fig1 


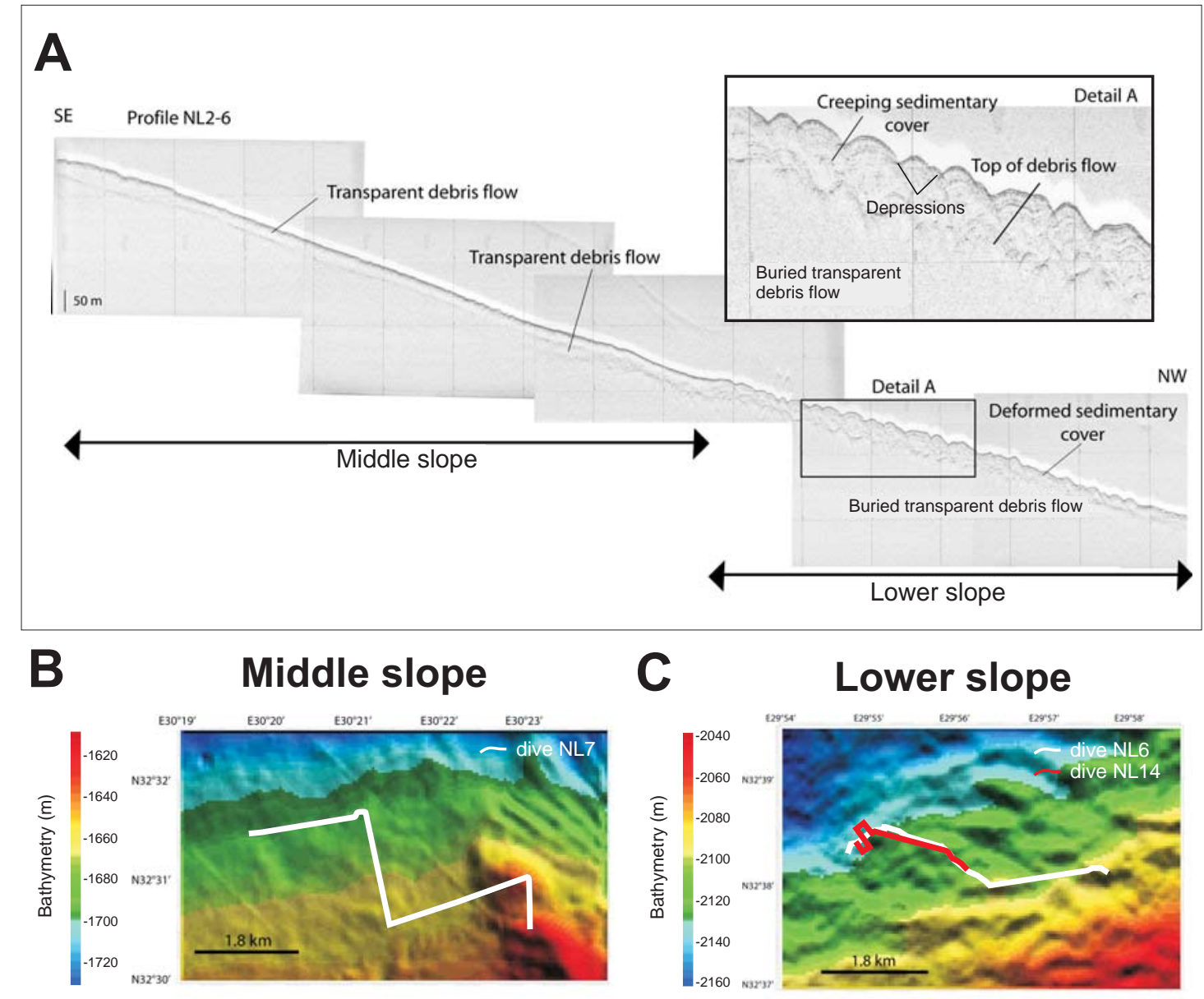

Fig2 
A

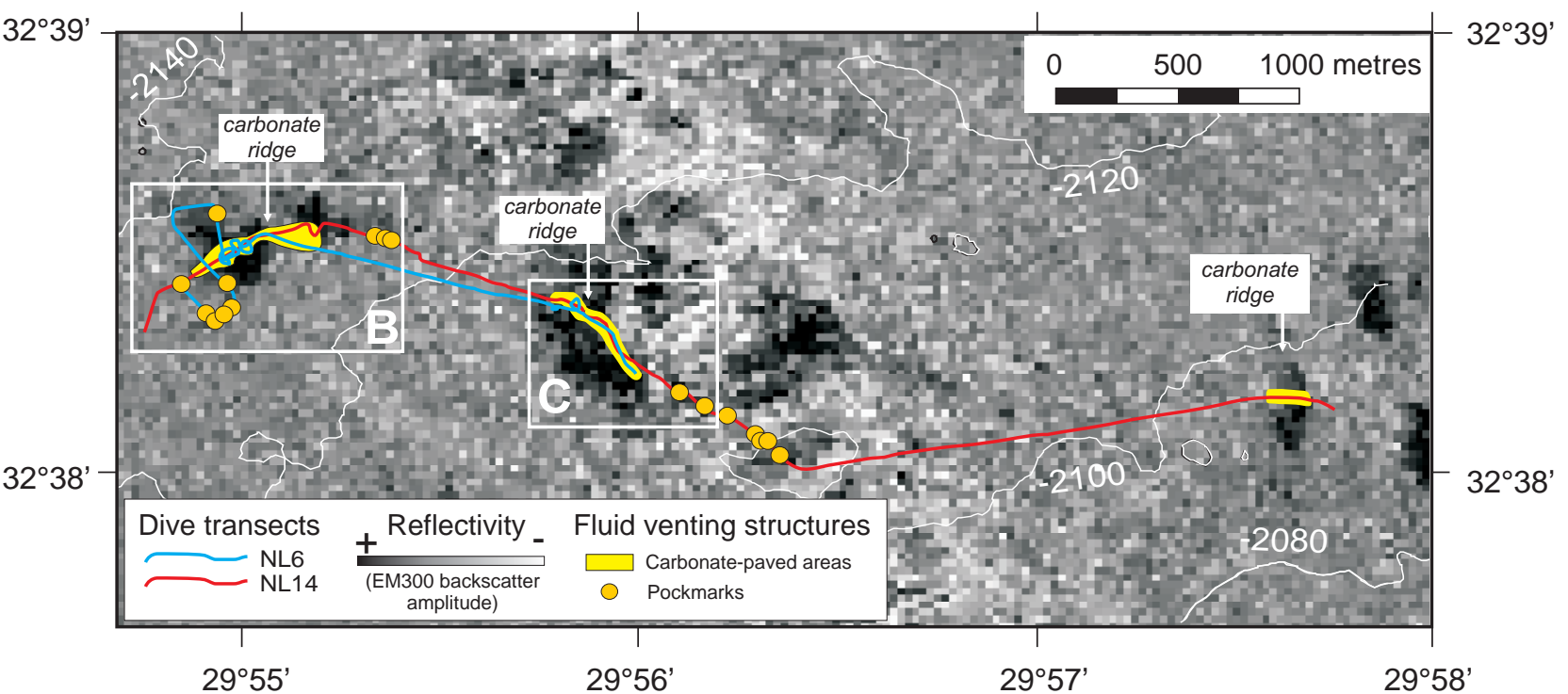

\section{B}
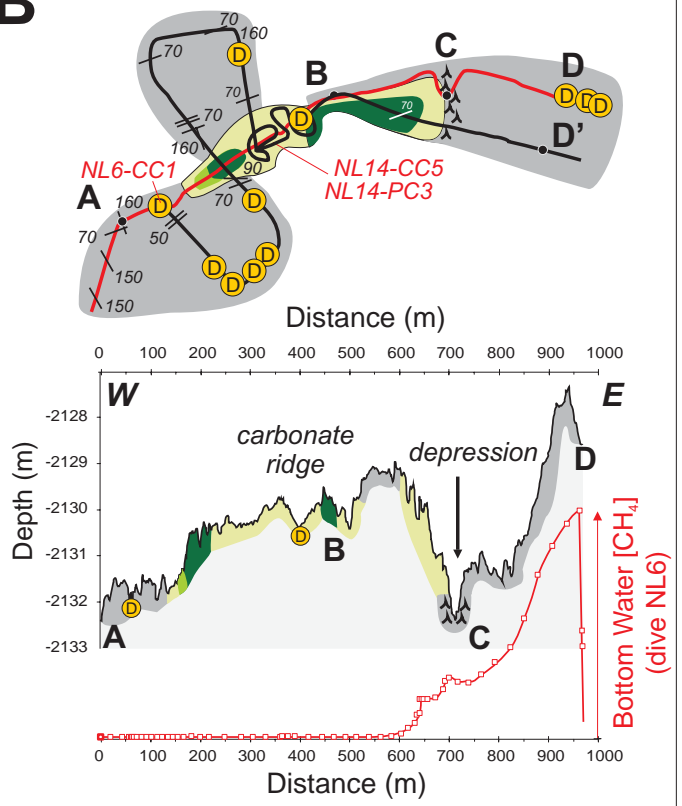

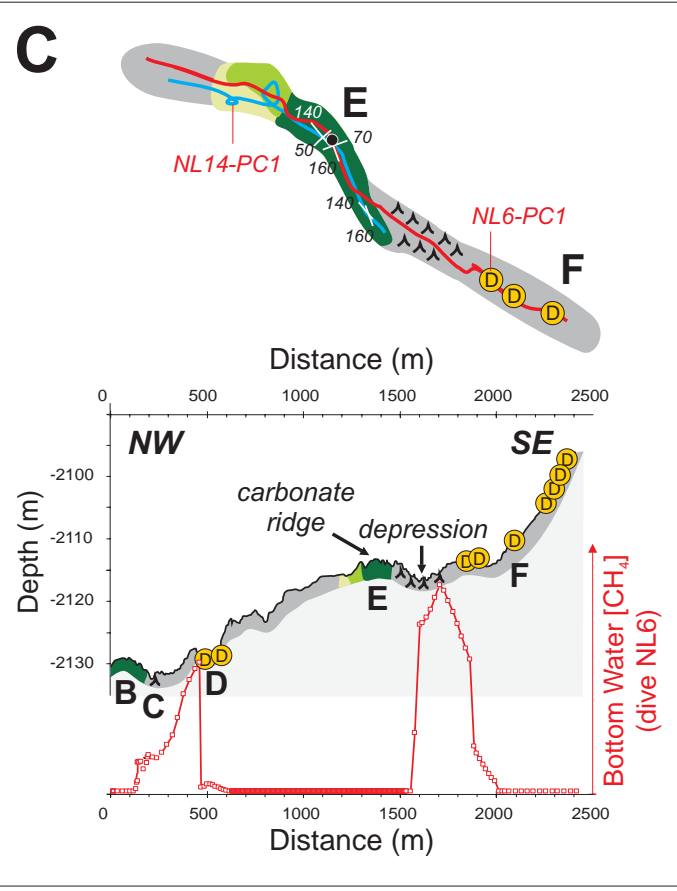

\section{Legend}

Fluid venting structures

(D) Pockmarks

Massive carbonate pavements

Fractured carbonate pavements

Carbonate crusts covered by sediments

Sediments

Brownish hemipelagic sediments

$\hat{\imath} \wedge \hat{\Lambda}$ Sediments associated with bioturbation mounds

Faults in sediments or carbonate pavements 


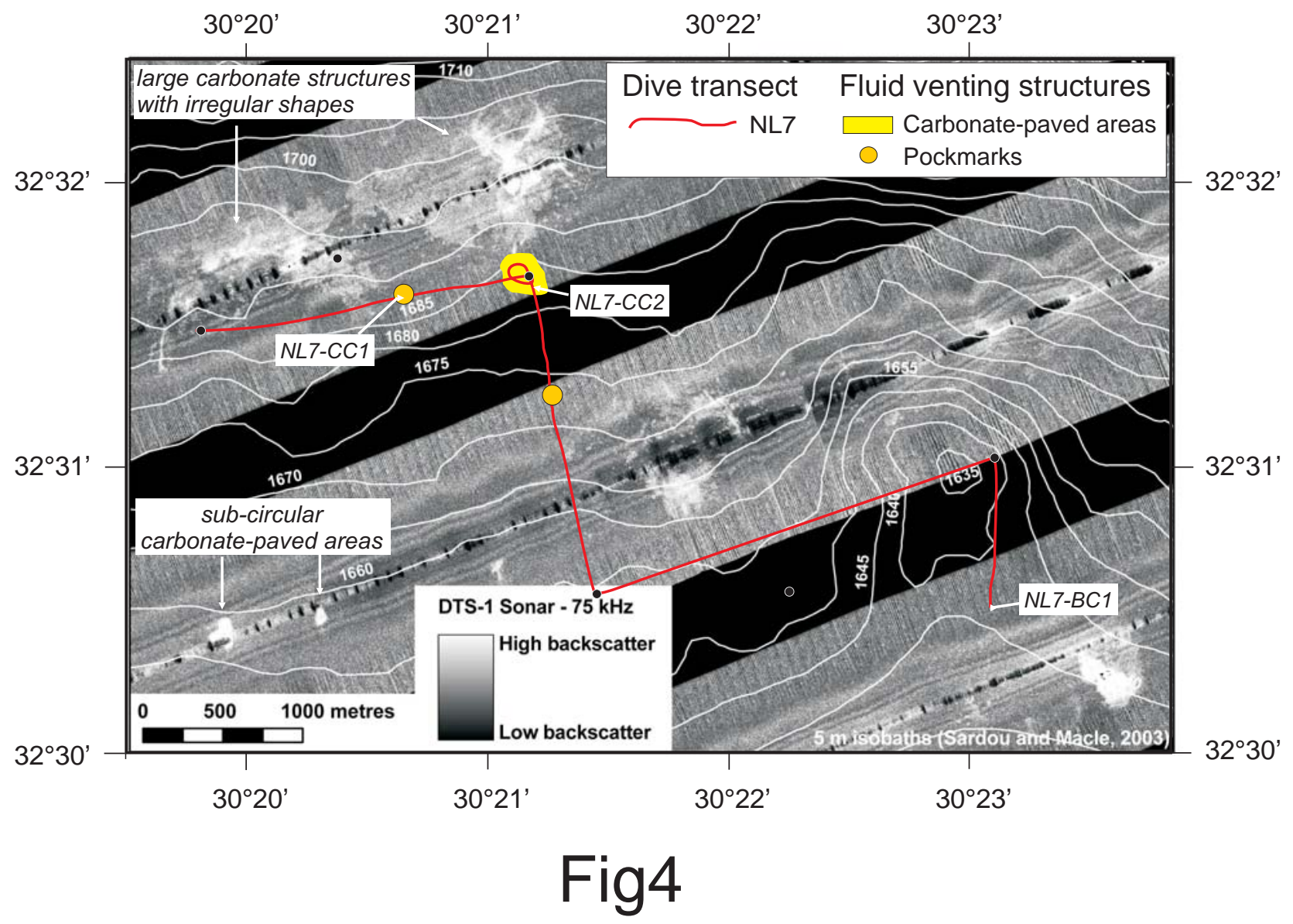



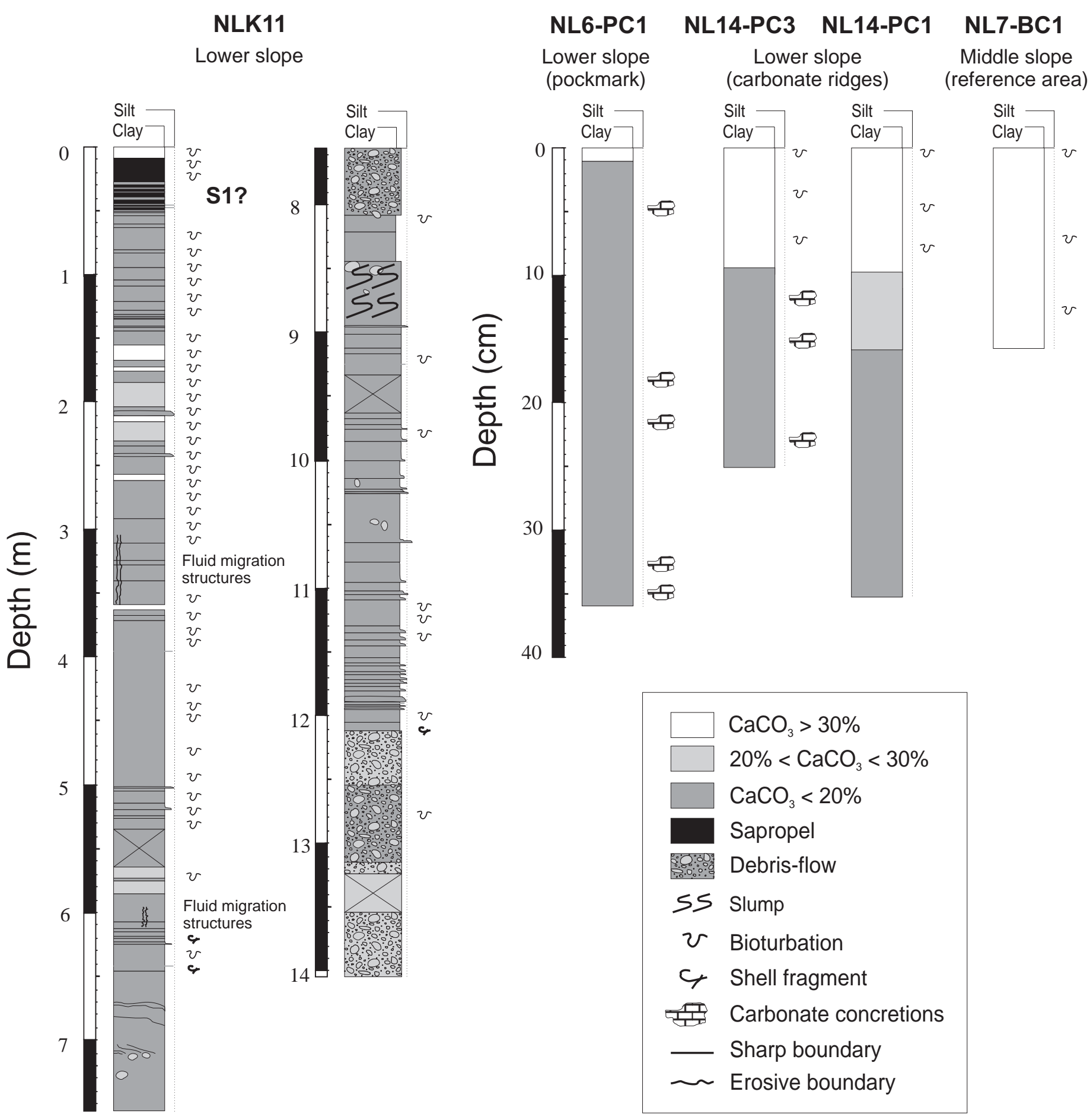

Fig5 

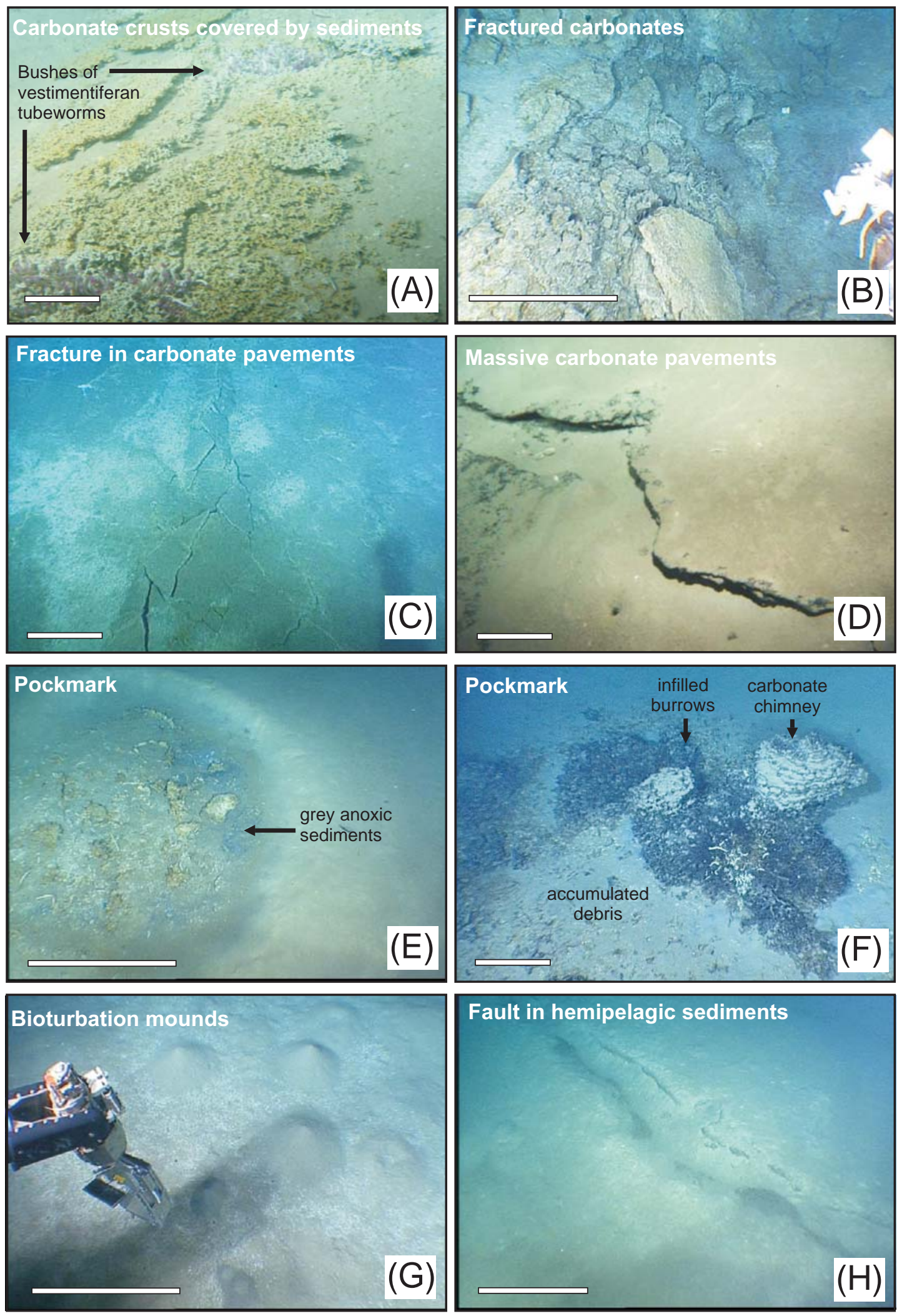

Fault in hemipelagic sediments

(H)

\section{Fig6}



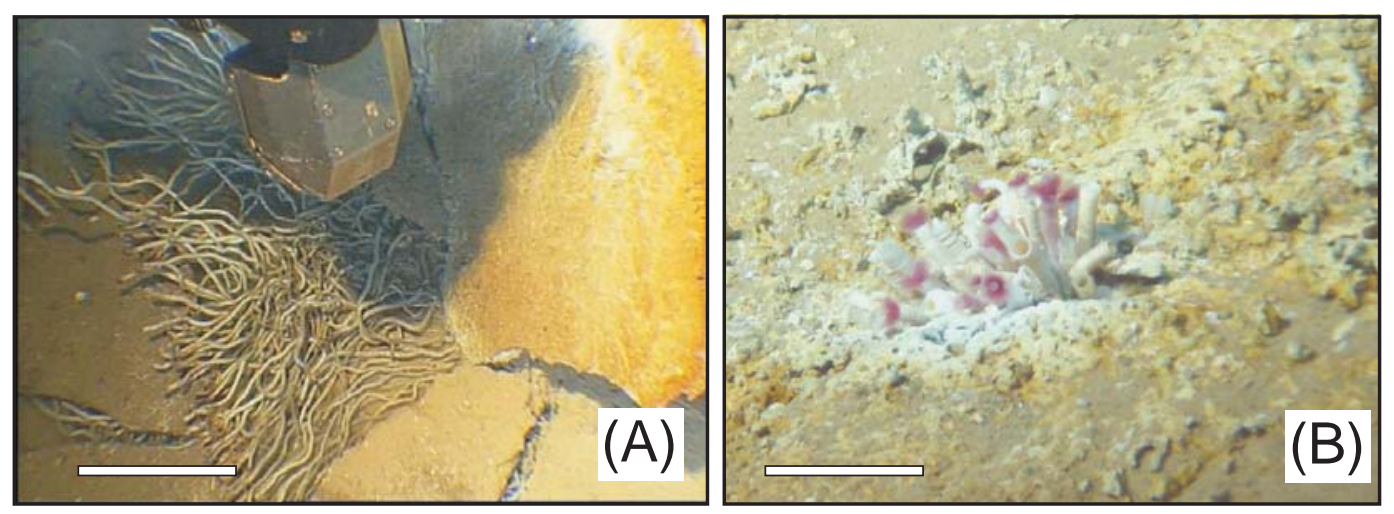

Fig7 

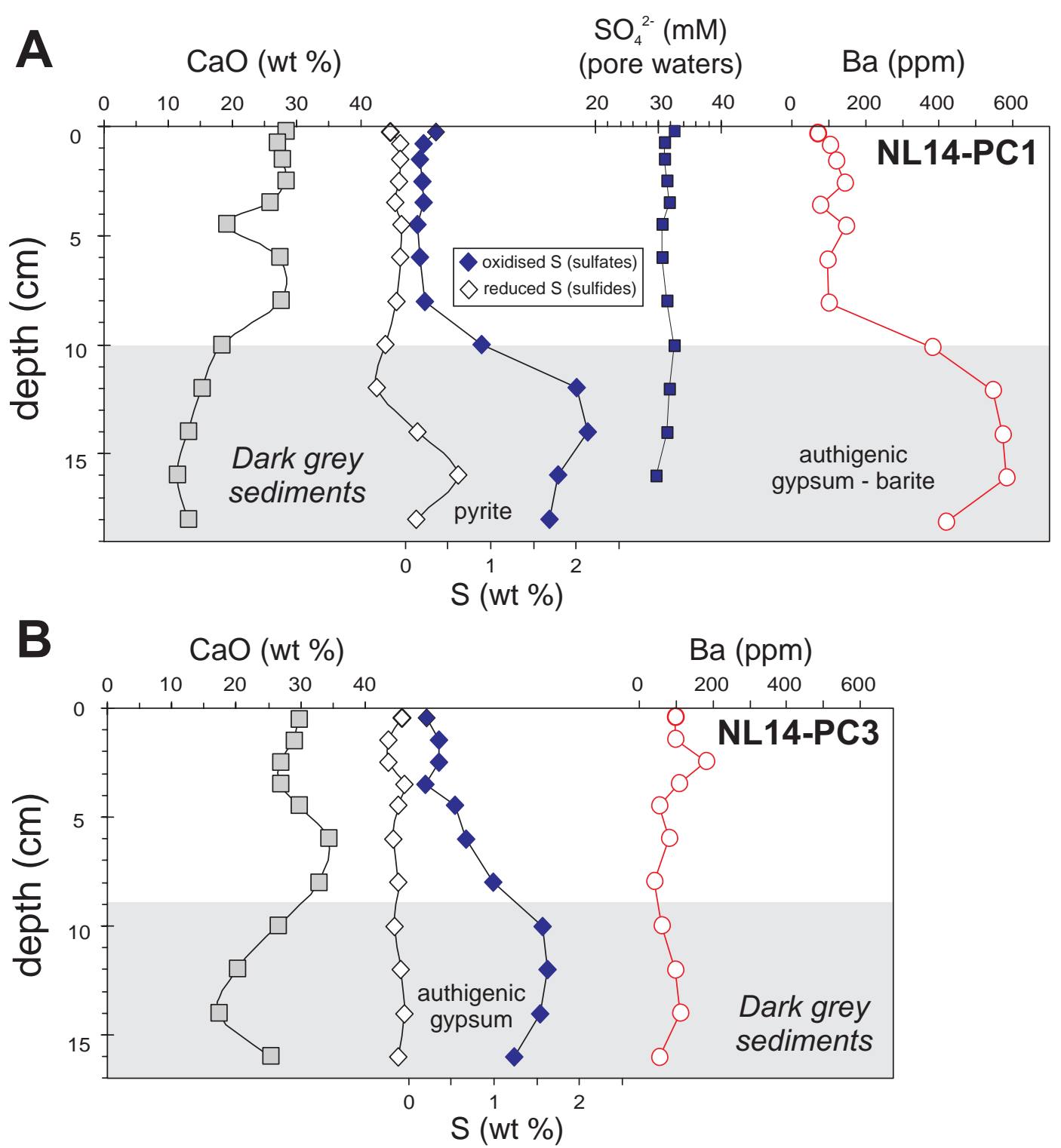

Fig8 


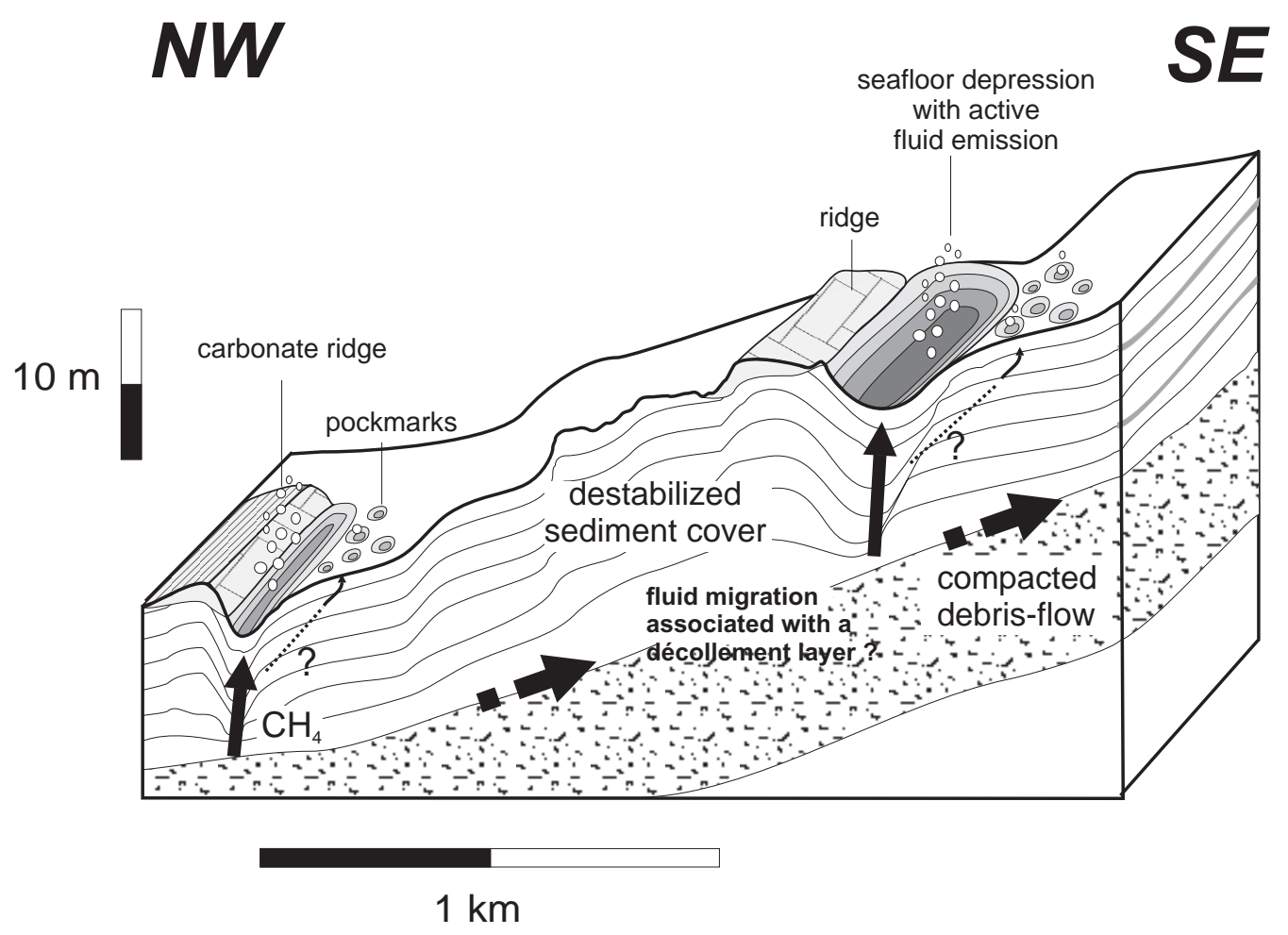

Fig9 